\title{
TREE-RING DATING OF OLD-GROWTH LONGLEAF PINE (PINUS PALUSTRIS MILL.) LOGS FROM AN EXPOSED TIMBER CRIB DAM, HOPE MILLS, NORTH CAROLINA, U.S.A.
}

\author{
SASKIA L. VAN DE GEVEL ${ }^{1}$, JUSTIN L. HART ${ }^{1}$, HENRI D. GRISSINO-MAYER ${ }^{1 *}$, and KENNETH W. ROBINSON ${ }^{2}$ \\ ${ }^{1}$ Laboratory of Tree-Ring Science, Department of Geography, The University of Tennessee, Knoxville, \\ Tennessee 37996, USA \\ ${ }^{2}$ Department of Anthropology, Wake Forest University, Winston-Salem, North Carolina 27109, USA
}

\begin{abstract}
On 26 May 2003, intense rainfall from a series of thunderstorms in eastern North Carolina caused flooding that eventually destroyed the concrete dam in Hope Mills, draining Hope Mills Lake, and revealing a formerly submerged and buried structure that was identified as a timber crib dam. Inspection revealed these logs to be old-growth longleaf pines, which are now rare on the coastal plain landscape. Our primary objective was to develop a new multi-century longleaf pine tree-ring chronology by crossdating the tree rings from sections extracted from logs in the crib dam with an anchored tree-ring chronology created from nearby living longleaf pine trees. We also examined the climatic response in the longleaf pine trees to evaluate their potential for reconstructing climate. Using tree-ring measurements obtained from old-growth longleaf pines found at a nearby church, we were able to date the rings on 21 series representing 14 logs from the crib dam, spanning the years 1597 to 1825. Distorted sapwood in many of the logs prevented us from finding absolute cutting dates and lessened the strength of correlation during the period of overlap between the church series and crib dam series. Human disturbances, specifically related to the naval stores industry, likely influenced the growth-ring patterns of the crib dam pine samples, as well. Correlation analyses between the longleaf pine chronology and temperature, precipitation, Palmer Drought Severity Indices, and North Atlantic sea surface temperatures showed a significant response to cool and wet spring months.
\end{abstract}

Keywords: Pinus palustris, old-growth longleaf pine, dendroarchaeology, North Carolina, Atlantic Coastal Plain.

\section{INTRODUCTION}

In the Southeastern U.S., dendrochronological techniques have been used to determine construction dates of historical structures (Bowers and Grashot 1976; Stahle 1979; Bortolot et al. 2001; Mann 2002; Grissino-Mayer and van de Gevel 2007), infer past landscape vegetation patterns (Druckenbrod and Shugart 2004), attain climate information that predates regional climate records (Grissino-Mayer 1993; Stahle et al. 1988; Fekedulegn et al. 2003), and identify the historical frequency of forest disturbance events (Nowacki and Abrams 1997; Schuler and McClain 2003; Guyette and Spetich 2004; Rubino and McCarthy

\footnotetext{
*Corresponding author: grissino@utk.edu; Fax 865974-6025; Telephone 865-974-6029
}

2004). In particular, dendrochronological research on historic structures is growing rapidly in the eastern U.S., largely because a need exists to authenticate and verify the construction dates of historic structures in the region (Mann 2002; Bannatyne 2005; Rosman 2005; Curtis 2006; Grissino-Mayer and van de Gevel 2007). However, more and more, these historical structures are being used to extend modern tree-ring chronologies into the 16th and 17th Centuries, both to help date other historical structures and prehistoric archaeological sites (Stahle 1979) and create longer chronologies to infer past climate on century time scales. Modern chronologies from long-lived tree species often overlap with oldgrowth timbers from these structures to help provide probable dates of construction. 
Before European settlement, open-canopied forests dominated by longleaf pine (Pinus palustris Mill.) occurred in communities throughout most of the southern Atlantic and Gulf Coastal Plains of the southeastern U.S. where fire commonly occurred (Platt et al. 1988; Christenson 2000). Beginning in the 17th Century, longleaf pine ecosystems began to deteriorate after extensive removal of trees for the naval stores industries and for timber, a practice that intensified in the 18th Century and the first half of the 19th Century. Other intensive land-use practices, such as livestock grazing, agricultural clearing, and the introduction of hogs, further resulted in the loss of old-growth longleaf pine forests, reducing the number of living trees that could provide tree-ring information on the ecological and cultural history of the Southeastern U.S. Only 3\% of the longleaf pines present on the Coastal Plain landscape prior to European settlement remain today (Simberloff 1993; Noel et al. 1998).

Despite the scarcity of old-growth longleaf pines, the species is considered ideal for dendrochronological research in the Southeastern U.S. because it is long-lived, its wood remains wellpreserved after death (partly because of large amounts of resin), and it shows high sensitivity to climate variations. Previous studies showed that longleaf pine radial growth is particularly sensitive to drought (Devall et al. 1991, Foster and Brooks 2001) and to winter and spring precipitation (Meldahl et al. 1999). The El Niño-Southern Oscillation (ENSO), the Pacific Decadal Oscillation (PDO), and the North Atlantic Oscillation (NAO) have also been shown to significantly affect longleaf pine growth on the Coastal Plain (Henderson 2006). The dendrochronological value of longleaf pine has spawned considerable interest in locating sites where old-growth longleaf pines or their remnants might be found.

On 26 May 2003, a series of thunderstorms caused 15 to $23 \mathrm{~cm}$ of rain to breach dams in the watershed of Rockfish Creek in Cumberland County, North Carolina (North Carolina Geological Survey 2007). In Hope Mills, North Carolina, these heavy rains filled Hope Mills Lake, but the sluice gates on the spillway failed to open, causing the earthen portions of the dam to breach and the

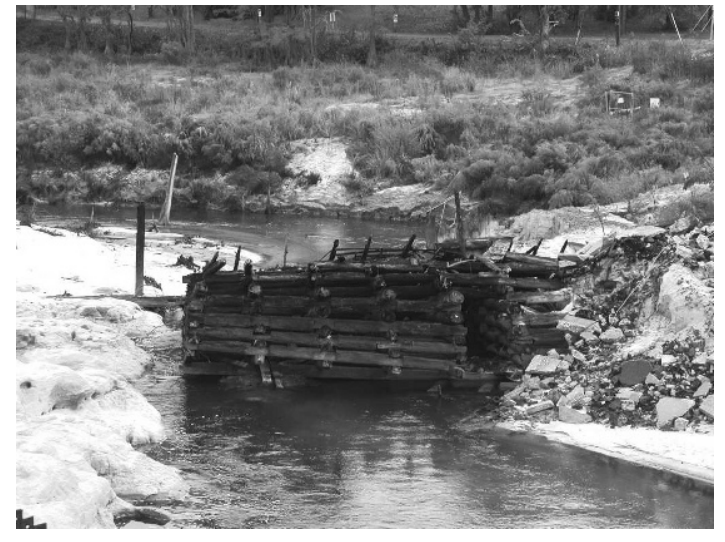

Figure 1. The Hope Mills crib dam in Little Rockfish Creek, North Carolina, after Hope Mills Lake drained and revealed the earthen dam (visible to the right) in May, 2003.

lake to drain rapidly. As the lake drained, the original channel of Little Rockfish Creek and its floodplain were exposed, revealing many large pine stumps from what once was an extensive forest of longleaf pines. To everyone's surprise, the draining of the lake also revealed several curious structures, including a $\log$ crib structure built of large cross-stacked logs (Figure 1). The log crib was an interior support structure for an earthen dam placed across Little Rockfish Creek. The crib provided structural integrity to the dam, and was filled and covered with earth. Timber crib construction was a common feature of 18th and 19th Century dams and other industrial sites, a time when the massive timbers of old-growth forests were still plentiful. The timbers provided the strength required for earthen dam construction (Robinson 2006). Recognized as an unusually well-preserved historic structure, the crib dam was archaeologically documented as part of a project to build a new bridge and dam across Little Rockfish Creek and restore Hope Mills Lake (Robinson 2006).

The log crib dam is part of a larger dam associated with one of the early textile mills of south-central North Carolina. The mill and dam were constructed in 1839 by the Rockfish Manufacturing Company. The dam site was originally selected because this stretch of Little Rockfish Creek was deeply incised into relatively stable clay subsoil. Two rectangular crib structures made of longleaf pine logs were set into the creek bed then 


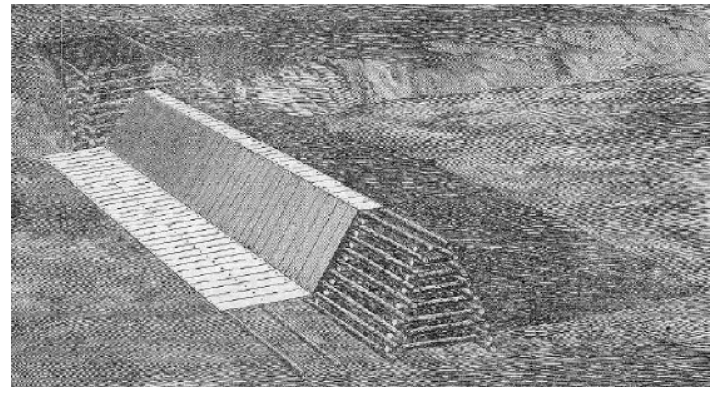

Figure 2. Sketch of a crib dam (Leffel 1874), similar to the crib dam built in the late 1830s at the Rockfish Manufacturing Company on Little Rockfish Creek, Hope Mills, North Carolina.

connected, eventually creating a structure that measured approximately $24 \mathrm{~m}$ in length and $12 \mathrm{~m}$ in width, with planks covering the log crib structure (Robinson 2006). One of the dams illustrated in a 19th Century guide to dam construction (Leffel 1874) is similar to the crib dam at Hope Mills, and shows the log structure, the plank covering, and the overlying fill (Figure 2). The earthen dam with the cribbed interior remained in use from 1839 until the 2003 flooding event, with the earthen portion of the dam heightened in the late 19th Century to add a cut timber spillway and dam, and later a concrete spillway.

The exhumed crib dam afforded a rare opportunity for us to collect complete crosssection samples from old-growth longleaf pine trees that are now very rare on the 21 st Century landscape. Our research had several objectives: (1) crossdate the tree rings from logs on the crib dam to develop a multi-century floating chronology, (2) externally crossdate and therefore anchor this chronology absolutely in time with another chronology developed from nearby living longleaf pine trees, and (3) examine the climate response of local longleaf pines using the final combined treering chronology.

\section{STUDY AREA}

The study site is located in the town of Hope Mills in south-central North Carolina on the Atlantic Coastal Plain (Figure 3). The Coastal Plain is a region of low local relief that ranges

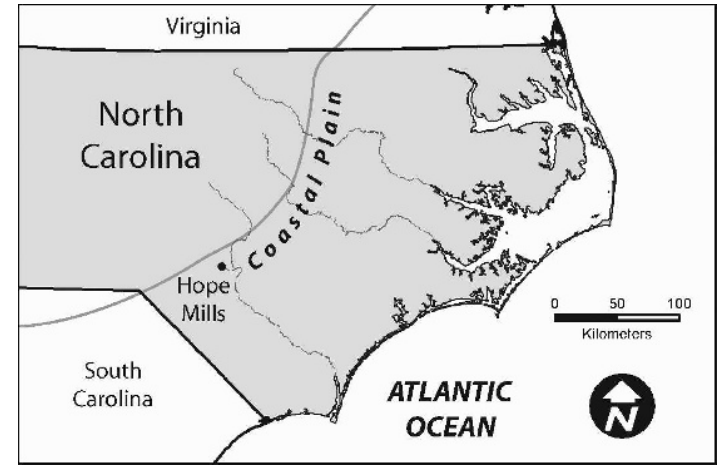

Figure 3. The longleaf pines used in this study came from Big Rockfish Presbyterian Church and the crib dam at Hope Mills Lake in Hope Mills, North Carolina (map by Josh Calhoun, Cartographic Services Laboratory, University of Tennessee, 2007).

from sea level to $90 \mathrm{~m}$ elevation and contains a high density of river networks (Fenneman 1938). Soils are mostly Udults (suborder of Ultisols: low organic-carbon content, reddish-yellow argillic horizons) and Aquults (Ultisols with aquic conditions: soil moisture nearly free of dissolved oxygen because of saturation by groundwater) ( $\mathrm{McNab}$ and Avers 1994). In the vicinity of Hope Mills, average monthly temperatures range from $12^{\circ} \mathrm{C}$ in January to $33^{\circ} \mathrm{C}$ in July, while monthly precipitation totals range from $7.0 \mathrm{~cm}$ in the dry months of October and November to $14.6 \mathrm{~cm}$ during the wettest month of July (Southeast Regional Climate Center (SRCC), 2007). Periodic hurricanes contribute to the disturbance regime in North Carolina coastal forests (Boutet and Weishampel 2003; McNab et al. 2004). This region also has a high frequency of lightning strikes, causing fires during the presettlement era to occur once every 1 to 3 years (Wright and Bailey 1982; Frost 1998), thereby making this region one of the most fireadapted ecosystems in the world (Van Lear et al. 2005).

\section{METHODS}

\section{Field Collection}

Because we could not sample every log, we prescreened each $\log$ and chose to sample those that exhibited longer sequences of narrow tree rings and were structurally sound. We were 
allowed to remove cross-sections using a chain saw because the old crib dam was going to be disassembled and removed from the site. Crosssections were appropriately labeled and wrapped in plastic shrink-wrap to ensure stability while being transported. We created a local anchored chronology from seven old-growth longleaf pine trees and three tree stumps found on the property of the Big Rockfish Presbyterian Church, located approximately $5 \mathrm{~km}$ southeast from the Hope Mills crib dam. Two cores from each tree were extracted with an increment borer approximately $30 \mathrm{~cm}$ above ground level and at $180^{\circ}$ from each other, while a chain saw was used to obtain complete sections from the stumps of nearby trees that had been damaged by Hurricane Fran in 1996. Core samples were labeled and placed in paper straws before being transported to the laboratory.

\section{Laboratory Methods}

Tree cores were allowed to air-dry completely in the straws and were then glued to wooden core mounts with cells vertically aligned to ensure a transverse view of the wood surface. Crosssections and cores were surfaced using progressively finer sandpaper, beginning with 100 -grit and ending with 400-grit (Orvis and Grissino-Mayer 2002). This process produced a wood surface with cellular features clearly defined under $10 \times$ magnification for clear ring identification. We drew two radii on each cross-section extending from the pith to the outermost complete ring along which to measure, bypassing particularly eroded and degraded portions of the surface.

\section{Crossdating}

We crossdated each tree-ring series against all others ("internal crossdating") using the skeleton plot technique (Swetnam et al. 1985; Stokes and Smiley 1996) and confirmed our dating with the computer program COFECHA (Holmes 1983; Grissino-Mayer 2001). The internal crossdating process began by assigning the innermost complete ring on each cross-section the relative year " 1 " and marking every subsequent tenth ring with a mechanical pencil. The skeleton plots helped ensure all rings were identified in the cores taken from living trees, but skeleton plots for tree rings on the cross-sections did not always indicate clear crossdating, especially in the outermost rings.

We then measured the ring widths on all samples to $0.001 \mathrm{~mm}$ accuracy with a Velmex measuring stage coupled with MEASURE J2X software. We confirmed the graphical crossdating and relative placements of all tree-ring series using COFECHA, which uses segmented time-series correlation techniques to confirm the temporal placements of all tree rings (Grissino-Mayer 2001). Because crossdating is a "high-frequency" process (pattern matching of sequences of individual rings), COFECHA removes all low-frequency trends using both spline-fitting algorithms and autoregressive modeling (Grissino-Mayer 2001). Such trends could also be caused by natural (e.g. local floods from Little Rockfish Creek that might damage the surface of the timbers) and human (e.g. turpentining and logging) disturbances that otherwise could mask the climate signal desirable for accurate crossdating. We tested consecutive 50 -yr segments (with 25-yr overlaps) on each series with a temporary master chronology created from all other series. Crossdating was verified when the correlation coefficient for each tested segment exceeded $0.32(p<0.01)$, although coefficients were usually much higher (for example, $r>0.51$, $\mathrm{p}<0.0001$ ).

External crossdating was achieved by using COFECHA to compare the undated ("floating") chronology from the crib dam logs with our anchored longleaf pine church samples. The final suggested placement made by COFECHA had to be convincing both graphically (similar patterns in wide and narrow rings) and statistically (correlation significant at $\mathrm{p}<0.001$ ) (Grissino-Mayer 2001). Once confirmed, we assigned calendar years to all rings in the undated series. Crossdating quality was assessed by two statistical descriptors. The average mean sensitivity was used to measure the strength of the year-to-year variability in all series. Values of 0.20 are common for tree-ring data from the southeastern USA (DeWitt and Ames 1978). We also used the average interseries correlation, calculated in COFECHA by averag- 
ing together the interseries correlation for each series (Grissino-Mayer 2001).

\section{Standardization}

We standardized all series to remove effects from age-related growth trends and possible natural or human disturbances that could add noise to the tree growth series unrelated to the climate signal desired in chronology development (Cook 1987; Fritts 2001). An index of growth was created by dividing each ring measurement by the predicted value of growth based on a trend line. Once each individual series was standardized, the final master chronology was created from all treering series from the living and dead old-growth longleaf pine trees from the church and from the Hope Mills crib dam. The indices were averaged by year from all series using the program CRONOL (Cook 1985; Holmes 1992). Only the portion of the chronology represented by two or more series was statistically evaluated for quality control and final absolute crossdating.

\section{Climate Response}

We compared longleaf pine growth with climate via correlation techniques that used North Carolina Climate Division 5 data from the National Climate Data Center (NCDC 2007). The period for analysis spanned 1940 to 2003. Climate variables analyzed included monthly average temperature, monthly total precipitation, and monthly Palmer Drought Severity Index (PDSI). PDSI is a meteorological index that describes the severity of wet and dry periods and integrates temperature, precipitation, and evapotranspiration as an estimate of soil moisture availability (Palmer 1965). We computed correlation coefficients between annual growth indices and the three climate variables for a 16-month period (previous year May-current August).

\section{RESULTS}

\section{Descriptive Statistics}

The average mean sensitivity was 0.29 with the lowest value of 0.23 for $\mathrm{HMCDBC} 2 \mathrm{~B}$ and highest value of 0.42 for HMCHS02A (Table 1). This value is within the range of those found for the five longleaf pine data sets held in the International Tree-Ring Data Bank (ITRDB 2005) and for three recently developed longleaf pine chronologies for Texas, Florida, and South Carolina (Henderson 2006) (range among eight sites from 0.25 for a site in North Carolina to 0.36 for a site in Georgia). These results indicate the sampled trees were average for this species in their sensitivity to year-to-year environmental fluctuations. The average inter-series correlation for the 39 Hope Mills cores and cross-sections was 0.52 (lowest $=0.42$ for HMCHR03A and HMCDSD2B, $\mathrm{n}=223$ and 136 years, respectively, $\mathrm{p}<0.001$ for both nonetheless; highest $\mathrm{r}=0.64$ for HMCHR06B, $\mathrm{n}=267$ years, $\mathrm{p}<0.0001$; Table 1 ). This value is again in the middle of the range of values for the eight longleaf pine sites contained in the ITRDB and those developed by Henderson (2006) (range from 0.42 for a site in North Carolina to 0.60 for a site in Georgia).

\section{Crossdating and Outermost Dates}

The Hope Mills longleaf pine chronology was anchored from 1597 to 2003 by combining the anchored longleaf pine samples from Big Rockfish Presbyterian Church with those from the Hope Mills crib dam (Figure 4). Visibly noticeable narrow rings in the chronology were formed in 1657, 1730, 1755, 1777, 1826, 1837, 1922, 1927, 1946, 1968, 1995 (although the actual magnitudes of the indices vary) and served as marker rings for crossdating (Baillie 1988). Periods of reduced growth from 1650-1660, 1820-1830, and 1910-1950 were also used in the crossdating process. Crossdating was less consistent from 1725 to 1800 because of low sample depth. The outermost dates for the 12 logs from the Hope Mills crib dam varied from 1750 to 1825 . We found one period of clustered dates for seven logs from 1800 to 1820 (Table 2). Only one log had an outermost date after 1820 (HMCD5B5A, outermost ring $=1825$ ). The outermost rings from these samples were not cutting dates because the logs contained decayed and deformed sapwood caused by pressure from burial, and bark was not present to verify the date of tree harvesting. 
Table 1. Descriptive statistics for tree-ring series from the Hope Mills crib dam and Big Rockfish Presbyterian Church.

\begin{tabular}{|c|c|c|c|c|}
\hline Series * & Begin Year & End Year & Inter-series Correlation & Mean Sensitivity \\
\hline HMCHR01A & 1767 & 1965 & 0.46 & 0.25 \\
\hline HMCHR01B & 1767 & 1965 & 0.49 & 0.26 \\
\hline HMCHR02A & 1764 & 2003 & 0.55 & 0.29 \\
\hline HMCHR02B & 1780 & 2003 & 0.54 & 0.27 \\
\hline HMCHR03A & 1780 & 2003 & 0.42 & 0.36 \\
\hline HMCHR04A & 1730 & 2003 & 0.52 & 0.29 \\
\hline HMCHR04B & 1736 & 2003 & 0.64 & 0.28 \\
\hline HMCHR05A & 1770 & 2003 & 0.61 & 0.26 \\
\hline HMCHR05B & 1740 & 1965 & 0.53 & 0.23 \\
\hline HMCHR06A & 1727 & 2003 & 0.50 & 0.31 \\
\hline HMCHR06B & 1727 & 2003 & 0.64 & 0.34 \\
\hline HMCHR07A & 1759 & 2003 & 0.60 & 0.25 \\
\hline HMCHR07B & 1760 & 2003 & 0.58 & 0.26 \\
\hline HMCHS01A & 1761 & 1944 & 0.45 & 0.26 \\
\hline HMCHS01B & 1761 & 1937 & 0.50 & 0.29 \\
\hline HMCHS02A & 1727 & 1884 & 0.43 & 0.42 \\
\hline HMCHS02B & 1730 & 1890 & 0.53 & 0.36 \\
\hline HMCHS03A & 1729 & 1965 & 0.51 & 0.34 \\
\hline $\mathrm{HMCDBC} 2 \mathrm{~A}$ & 1739 & 1814 & 0.50 & 0.24 \\
\hline HMCDBC2B & 1739 & 1816 & 0.48 & 0.23 \\
\hline HMCDEC3A & 1601 & 1790 & 0.49 & 0.28 \\
\hline HMCDEC3B & 1601 & 1740 & 0.44 & 0.25 \\
\hline HMCDEC4A & 1604 & 1795 & 0.45 & 0.33 \\
\hline HMCDEC4B & 1604 & 1804 & 0.48 & 0.33 \\
\hline HMCDED3A & 1597 & 1798 & 0.51 & 0.24 \\
\hline HMCDED3B & 1597 & 1774 & 0.50 & 0.24 \\
\hline HMCDSA4A & 1612 & 1817 & 0.48 & 0.23 \\
\hline HMCDSA4B & 1612 & 1798 & 0.62 & 0.27 \\
\hline HMCDSB5A & 1743 & 1825 & 0.45 & 0.29 \\
\hline HMCDSB5B & 1743 & 1816 & 0.48 & 0.30 \\
\hline HMCDSD2B & 1680 & 1816 & 0.42 & 0.23 \\
\hline HMCDSD5A & 1651 & 1750 & 0.46 & 0.30 \\
\hline HMCDSD5B & 1629 & 1728 & 0.56 & 0.28 \\
\hline HMCDSD7A & 1674 & 1802 & 0.60 & 0.34 \\
\hline HMCDSE4A & 1640 & 1804 & 0.52 & 0.29 \\
\hline HMCDSE4B & 1640 & 1810 & 0.46 & 0.30 \\
\hline HMCDSF4A & 1627 & 1803 & 0.51 & 0.30 \\
\hline HMCDSF4B & 1621 & 1781 & 0.52 & 0.32 \\
\hline HMCDSG6B & 1658 & 1770 & 0.50 & 0.32 \\
\hline
\end{tabular}

*HMCH: Hope Mills Church; HMCD: Hope Mills Crib Dam

\section{Climate Response}

Temperature from the previous year May and June, and during the current growing season from April to July were negatively correlated $(p<0.05)$ to longleaf pine tree growth from 1940 to 2003 (Figure 5). Tree growth responds positively to precipitation during May of the current growing season, but negatively to wet conditions in July of the previous year and August of the current year. The most significant relationship between tree growth and climate was found using PDSI, which showed positive responses to overall wet conditions in the late spring and early summer of the current growing season. Longleaf pines growing on the coastal plain of North Carolina grow best when spring temperatures are cool and spring rainfall is abundant. Low rainfall amounts during spring exacerbated by high temperatures likely result in reduced growth. 


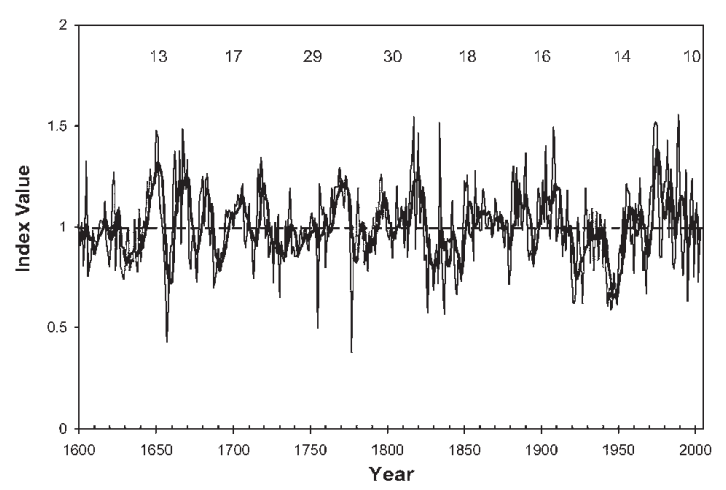

Figure 4. The 400-year longleaf pine chronology, composed of cores from living trees and cross-sections from the Hope Mills crib dam. Numbers at top represent sample depth of series.

\section{DISCUSSION}

The chronology developed from the cores and cross-sections taken from the Big Rockfish Presbyterian Church $(n=10)$ overlapped with the logs collected from the Hope Mills crib dam $(\mathrm{n}=$ 12) for 99 years from 1727 to 1825. Many correlations for the 50-year segments for series from the crib dam during this period were statistically insignificant $(r<0.32, p>0.01)$ because the outermost rings from these series were highly eroded and distorted by burial. A longer overlap with a larger sample depth is desirable and would have strengthened the crossdating of samples between the old-growth longleaf pine trees at Big Rockfish Presbyterian Church and the Hope Mills crib dam. Nonetheless, some correlations for these 50 -years segments from the crib dam were statistically significant during the period of overlap (e.g. HMCDSF4A, HMCDED3A, and HMCDED3B; Table 2), and nearly all correlations were positive, signifying greater agreement among the series than disagreement.

Ideally, additional samples should be collected that will help strengthen the agreement between the living trees and the buried logs during the period of overlap. We identified three potential sources of such wood. First, abutment timbers of a plank road were found in Hope Mills near the lake, one of five plank roads (known as the "Fayetteville and Southern Plank Road" built $c a$. 1849-1850) that connected the nearby "hub" town of Fayetteville to other parts of the state before rail lines were constructed (Robinson 2006). Plank roads were made of pine and these timbers are in an excellent state of preservation, likely because of their high resin content. Second, wooden pilings and timber supports of a railroad trestle that once spanned Little Rockfish Creek on the northern end of Hope Mills Lake (100 m to the east of the modern railroad bridge) are present in the creek and on both creek banks. Inspection revealed these timbers to be old-growth longleaf pines, many with well over 250 rings. Finally, the many stumps left over from building these structures and others in Hope Mills in the 1800s literally dot the former shoreline of the lake and former floodplain of Little Rockfish Creek. Many of the stumps show felling by axes, some show evidence of turpentining, and all are in excellent condition.

In addition to the distorted rings in the sapwood of the crib dam logs, the overall ring patterns from the longleaf pines may have been further affected in previous decades by a significant human-caused disturbance that would not be visible on logs used in the crib dam construction. From the mid-18th Century until the middle of the 19th Century, North Carolina was one of the largest New World producers of gum naval stores and turpentine from longleaf pines (Perry 1968; Robinson 1988, 1991; Gerrell 1998; Butler 1998; Grissino-Mayer et al. 2001). To collect resin, workers would use an ax to create a cavity or "box" at the base of the pine tree trunk, then "chip" or streak away bark, phloem, and outer xylem above the box to induce flow of resin outside the cut area and downward to the box where resin was collected (Frost 1993; Butler 1998; Grissino-Mayer et al. 2001). It is very likely that the trees used in the crib dam were previously used for producing resin before they were harvested, because all boxed trees would later be logged once they no longer produced resin (Butler 1998). Some longleaf pine stumps that currently sit in the original floodplain showed clear signs of being used for gum naval stores production (Figure 6). The trees had been cut above the boxed and chipped area, verifying that this disturbance would not be visible on the logs of the crib dam. Pine trees could produce resin for many years, and could also be chipped two or even three times in their lifetime. The lower but still statistically 


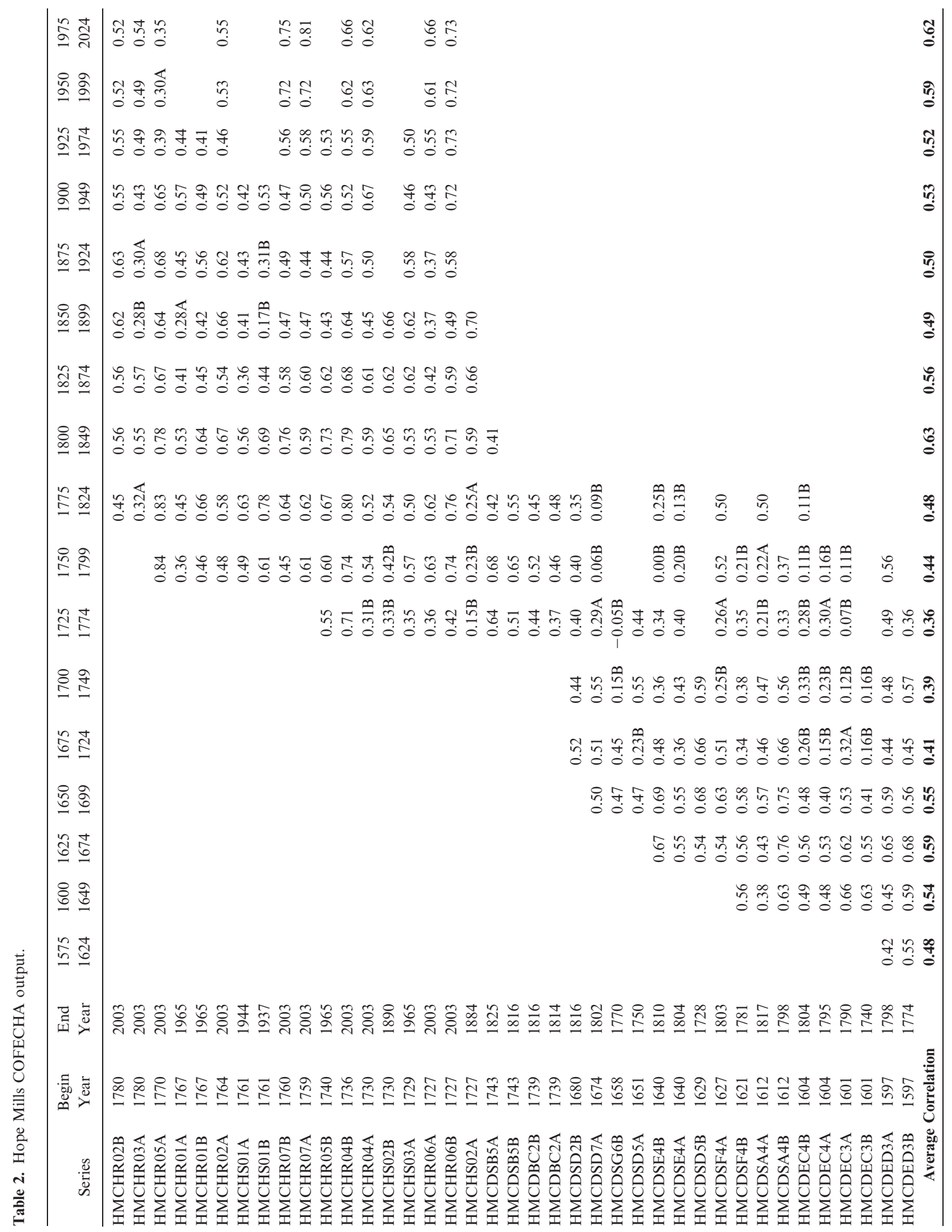




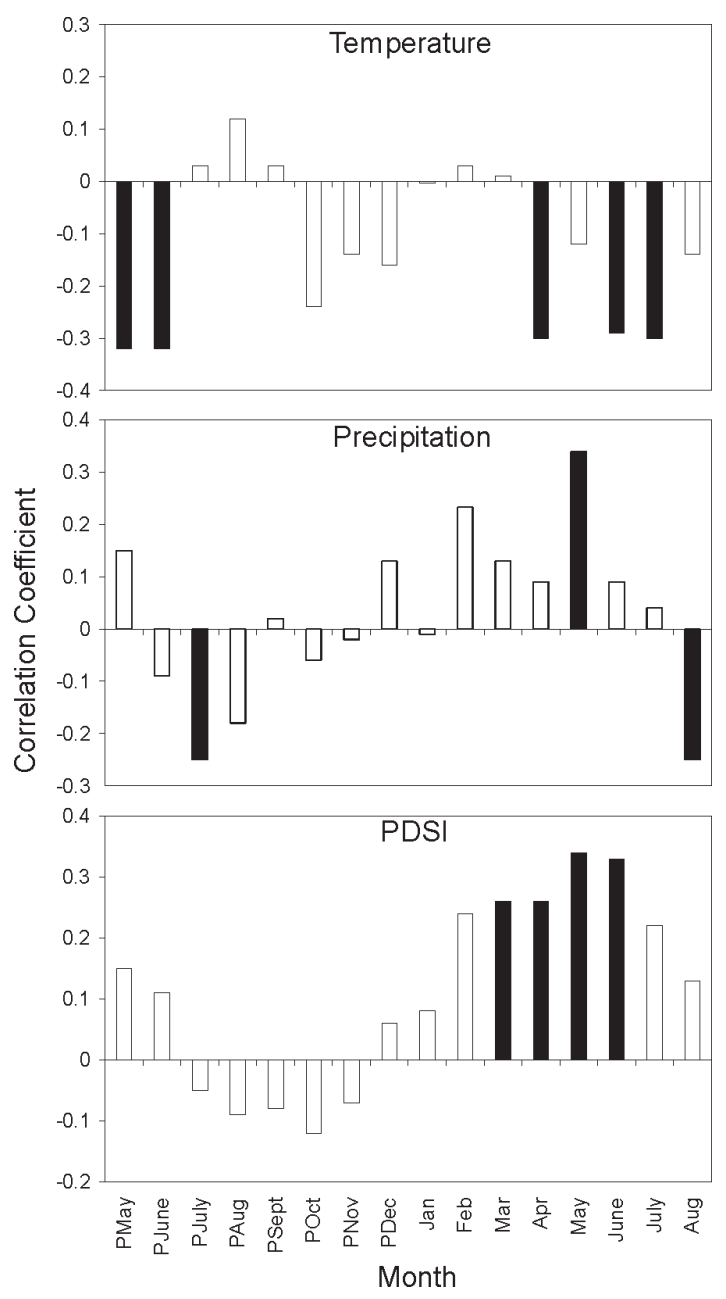

Figure 5. Correlation coefficients between the longleaf pine chronology and monthly (A) average temperature, (B) total precipitation, and (C) Palmer Drought Severity Index (PDSI). Black bars indicate significant correlations $(\mathrm{p}<0.05)$. Months span previous year May to current August.

significant correlations for many 50 -year segments from the crib dam logs could reflect the effects of human-caused disturbances to these trees. Furthermore, the weakened state of these pine trees would have made them vulnerable to other local disturbances and less responsive to climate, which would further lower the strength of crossdating for the crib dam logs.

The outermost dates for rings of the longleaf pine crib dam logs are not cutting dates because of the physical weathering and erosion of bark and sapwood on the buried logs during the past two

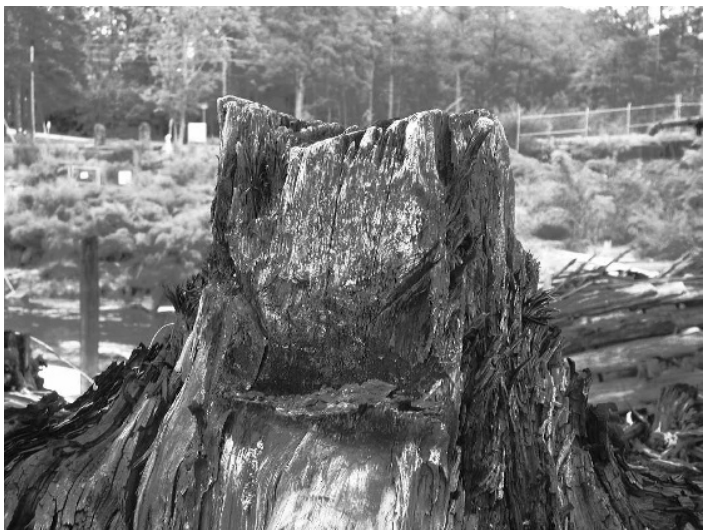

Figure 6. A "boxed" (cavity at the bottom for collecting resin) and "chipped" (angled streaking above the box) longleaf pine stump next to Little Rockfish Creek, less than $10 \mathrm{~m}$ away from the Hope Mills crib dam. This and many other longleaf pine stumps were revealed when the Hope Mills Lake drained in 2003.

centuries. The pressure of overlying sediment and impounded water and the movement of water and sediment in suspension abraded the sapwood, resulting in the loss of bark and outer xylem rings. The sapwood was intact on many of the logs but remained structurally unstable. We measured these rings nonetheless but found these rings problematic for crossdating. Had historical documentation not been available, the outer dates for the crib dam logs would have indicated the dam was constructed sometime after 1825, the youngest ring on any log (sample HMCDSB5A). Rockfish Manufacturing Company was incorporated in 1837 and the mill and dam were completed by 1839 (Robinson 2006). The cotton mill was likely operating by early 1840 , so the logs were likely cut sometime in late 1837 or sometime during the year of 1838. Our dendrochronological analyses therefore corroborate the information found in the historical documents, although not with the precision that we had hoped for because the exact cutting dates of the logs could not be determined.

We found that radial growth of longleaf pines from the church site responds favorably to cool, wet springs and moderate summers, results similar to those found for southern yellow pines elsewhere in the southeastern U.S. (Devall et al. 1991; Grissino-Mayer and Butler 1993; Henderson 2006). Longleaf pines are more sensitive to warm summer temperatures when evapotranspiration 
rates are higher and the effects of precipitation are more limited. Although oceanic effects tend to moderate coastal temperatures, the coastal plain region around Fayetteville, North Carolina, can experience temperatures of $38^{\circ} \mathrm{C}$ anytime from early May until late September (SRCC 2007), with average summer temperatures of $32^{\circ} \mathrm{C}$. High temperatures and abundant rainfall in the previous year's growing season precondition growth in the following year by causing growth reduction and a tree ring narrower than average. The trend of statistically significant, positive correlations between longleaf pine growth and PDSI in the spring and summer months confirm the integrative response by these pines to both precipitation and temperature. Although the living longleaf pines indicate that a climate reconstruction may be possible, interpretations of past climate from logs used in the crib dam should be mindful of the possible effects of human disturbances on these logs, although averaging the growth indices from these $\operatorname{logs}$ by year during the standardization process could minimize these effects.

\section{ACKNOWLEDGMENTS}

We wish to thank William Terrell, Michael Murrow, and Jon Anders, Wake Forest University, Archaeology Laboratories for archaeological field documentation; Dr. Paul Thacker, Assistant Professor of Anthropology, Wake Forest University, for his support of the Public Archaeology Program; John M. Ray, Jr., District Conservationist, with the Natural Resources Conservation Service in Cumberland County, N.C. for providing access to the longleaf pines at Big Rockfish Presbyterian Church; and, the Town of Hope Mills, N.C. and The Rose Group, Engineers and Surveyors, for funding and support of the archaeological data recovery investigations. S.L. van de Gevel and J.L. Hart were partially supported by NSF grant number DGE-0538420.

\section{REFERENCES CITED}

Baillie, M. G. L., 1988. Marker dates-turning prehistory into history. Archaeology Ireland 2(4):154-155.

Bannatyne, L., 2005. Every tree has a story to tell. Christian Science Monitor. March 8, 2005.
Bortolot, Z. J., C. A. Copenheaver, R. L. Longe, and J. A. N. van Aardt, 2001. Development of a white oak chronology using live trees and a post-Civil War cabin in south-central Virginia. Tree-Ring Research 57:197-203.

Boutet, J. C., and J. F. Weishampel, 2003. Spatial pattern analysis of pre- and post-hurricane forest canopy structure in North Carolina, USA. Landscape Ecology 18(6):553-559.

Bowers, L. J., and D. L. Grashot, 1976. Results of the First Hermitage dendrochronological study. In An Archaeological and Historical Assessment of the First Hermitage, edited by S. D. Smith, pp. 271-281. Division of Archaeology, Tennessee Department of Conservation, and The Ladies Hermitage Association, Nashville, Tennessee.

Butler, C. B., 1998. Treasures of the Longleaf Pines: Naval Stores. Tarkel Publishing, Shalimar, Florida.

Christenson, N. L., 2000. Vegetation of the southeastern Coastal Plain. In North American Terrestrial Vegetation, edited by M. G. Barber, and W. D. Billings, pp. 398-448. Cambridge University Press, Cambridge.

Cook, E. R., 1985. A Time Series Analysis Approach to TreeRing Standardization. Ph.D. dissertation, University of Arizona, Tucson.

, 1987. The decomposition of tree-ring series for environmental studies. Tree-Ring Bulletin 47:37-59.

Curtis, W., 2006. Lords of the rings. Preservation Magazine 58(3):42-46.

Devall, M. S., J. M. Grender, and J. Koretz, 1991. Dendroecological analysis of a longleaf pine (Pinus palustris Mill.) forest in Mississippi. Vegetatio 93:1-8.

DeWitt, E., and M. Ames, 1978. Tree-ring Chronologies of Eastern North America. Laboratory of Tree-Ring Research, Tucson, Chronology Series IV, Volume 1.

Druckenbrod, D. L., and H. H. Shugart, 2004. Forest history of James Madison's Montpelier plantation. Journal of the Torrey Botanical Society 131(3):204-219.

Fekedulegn, D., R. R. Hicks, Jr, and J. J. Colbert, 2003. Influence of topographic aspect, precipitation and drought on radial growth of four major tree species in an Appalachian watershed. Forest Ecology and Management 177(1-3): 409-425.

Fenneman, M. M., 1938. Physiography of the Eastern United States. McGraw-Hill, New York.

Fritts, H. C., 2001. Tree Rings and Climate. Blackburn Press, Caldwell, New Jersey.

Foster, T. E., and J. R. Brooks, 2001. Long-term trends in growth of Pinus palustris and Pinus elliottii along a hydrological gradient in central Florida. Canadian Journal of Forest Research 31:1661-1670.

Frost, C. C., 1993. Four centuries of changing landscape patterns in the longleaf pine ecosystem. In The Longleaf Pine Ecosystem: Ecology, Restoration, and Management: Proceedings of the 18th Tall Timbers Fire Ecology Conference, edited by S. M. Hermann, pp. 7-43. Tall Timbers Research Station, Tallahassee, Florida.

, 1998. Presettlement fire frequency regimes of the United States: A first approximation. In Fire in Ecosystem Management: Shifting the Paradigm from Suppression to Prescription: Proceedings of the 20th Tall Timbers Fire 
Ecology Conference, edited by T. L. Pruden, and L. A. Brennan, pp. 70-81. Tall Timbers Research Station, Tallahassee, Florida.

Gerrell, P., 1998. The Illustrated History of the Naval Stores (Turpentine) Industry. Southern Yellow Pine Publishing, Crawfordville, Florida.

Grissino-Mayer, H. D., 2001. Evaluating crossdating accuracy: a manual and tutorial for the computer program COFECHA. Tree-Ring Research 57:205-221.

Grissino-Mayer, H. D., and D. R. Butler, 1993. Effects of climate on growth of shortleaf pine (Pinus echinata Mill.) in northern Georgia: A dendroclimatic study. Southeastern Geographer 33:65-81.

Grissino-Mayer, H. D., H. C. Blount, and A. C. Miller, 2001. Tree-ring dating and the ethnohistory of the naval stores industry in southern Georgia. Tree-Ring Research 57:3-13.

Grissino-Mayer, H. D., and S. L. van de Gevel, 2007. Tell-tale trees: The historical dendroarchaeology of log structures at Rocky Mount, Piney Flats, Tennessee. Historical Archaeology 41(4):32-49.

Guyette, R. P., and M. A. Spetich, 2004. Fire history of oakpine forests in the Lower Boston Mountains, Arkansas, USA. Forest Ecology and Management 180(1-3):463-474.

Henderson, J. P., 2006. Dendroclimatological Analysis and Fire History of Longleaf Pine (Pinus palustris Mill.) in the Atlantic and Gulf Coastal Plain. Ph.D. dissertation, University of Tennessee, Knoxville.

Holmes, R. L., 1983. Computer-assisted quality control in treering dating and measurement. Tree-Ring Bulletin 43:69-78.

—, 1992. Program CRONOL. In International Tree-Ring Data Bank Program User's Manual, edited by H. D. GrissinoMayer, R. L. Holmes, and H. C. Fritts, pp. 56-57. Laboratory of Tree-Ring Research, University of Arizona, Tucson.

International Tree-Ring Data Bank (ITDRB), 2005. Data available at http://www.ngdc.noaa.gov/paleo/treering.html.

Langley, S. B. M., 2000. Tongues in trees: Archaeology, dendrochronology, and the Mulberry Landing Wharf. Maryland Historical Magazine 95:339-348.

Leffel, J., 1874. The construction of mill dams, comprising also the building of race and reservoir embankments and head gates, the measurement of streams, gauging of water supply, \&c. James Leffel and Co., Springfield, Ohio.

Mann, D. F., 2002. Dendroarchaeology of the Swaggerty Blockhouse, Cocke County, Tennessee. M.S. Thesis, University of Tennessee, Knoxville.

McNab, W. H., and P. E. Avers, 1994. Ecological Subregions of the United States: Section Descriptions. Administrative Publication WO-WSA-5. Washington, DC: U.S. Department of Agriculture, Forest Service.

McNab, W. H., C. H. Greenberg, and E. C. Berg, 2004. Landscape distribution and characteristics of large hurricanerelated canopy gaps in a southern Appalachian watershed. Forest Ecology and Management 196:435-447.

Meldahl, R. S., N. Peterson, J. S. Kush, and J. M. Varner III, 1999. Dendrochronological investigations of climate and competitive effects on longleaf pine growth. In Tree-Ring Analysis: Biological, Methodological, and Environmental
Aspects, edited by R. Wimmer, and R. E. Vetter, pp. 265-285. CABI publishing, Oxon, United Kingdom.

National Oceanic and Atmospheric Administration (NOAA), 1996. Climatological data annual summary, North Carolina 1996: NOAA, ISSN 045-0794, 101(13).

Noel, J. M., W. J. Platt, and E. B. Moser, 1998. Structural characteristics of old- and second-growth stands of longleaf pine (Pinus palustris) in the Gulf Coastal Region of the U.S.A. Conservation Biology 12:533-548.

North Carolina Geological Survey, 2007. North Carolina Natural Hazards Costs. http://www.geology.enr.state.nc.us/ Landslide_Info/costs.htm. Accessed 23 July 2007.

Nowacki, G. J., and M. D. Abrams, 1997. Radial-growth averaging criteria for reconstructing disturbance histories from presettlement-origin oaks. Ecological Monographs 67: 225-249.

Orvis, K. H., and H. D. Grissino-Mayer, 2002. Standardizing the reporting of abrasive papers used to surface tree-ring samples. Tree-Ring Research 58:47-50.

Palmer, W. C., 1965. Meteorological Drought. Washington D.C., U.S. Weather Bureau Research Paper No. 45.

Perry, P., 1968. The naval stores industry in the Old South, 1790-1860. Journal of Southern History 34(4):509-526.

Platt, W. J., G. W. Evans, and S. L. Rathbun, 1988. The population dynamics of a long-lived conifer (Pinus palustris). The American Naturalist 131:491-525.

Rubino, D. L., and B. C. McCarthy, 2004. Comparative analysis of dendroecological methods used to assess disturbance events. Dendrochronologia 21:97-115.

Robinson, K. W., 1988. Archaeology and the North Carolina Naval Stores Industry: A Prospectus. Manuscript prepared for the North Carolina Office of State Archaeology, Raleigh, NC. _ 1991. Archaeological Data Recovery at Weed's Lightwood Plant: An Early-Twentieth-Century Naval Stores Distillery, Cumberland County, North Carolina. Report prepared for the N.C. Department of Transportation, Division of Highways, Planning and Environmental Branch, Raleigh, NC.

, 2006. Archaeological and Historical Documentation: Historic Industrial and Transportation Structures, Hope Mills Lake, Hope Mills, North Carolina. Final Report. Wake Forest University Archaeology Laboratories, WinstonSalem, North Carolina.

Rosman, K., 2005. This not-so-old house. Wall Street Journal. April 8, 2005.

Simberloff, D., 1993. Species-area and fragmentation effects on old-growth forest: Prospects for longleaf pine communities. In The Longleaf Pine Ecosystem: Ecology, Restoration, and Management: Proceedings of the 18th Tall Timbers Fire Ecology Conference, edited by S. M. Hermann, pp. 1-13. Tall Timbers Research Station, Tallahassee, Florida.

Schuler, T. M., and W. R. McClain, 2003. Fire history of a ridge and valley oak forest. USDA Forest Service Research Paper NE-724:1-9.

Southeast Regional Climate Center (SRCC), 2007. Fayetteville, North Carolina. Daily Temperature Averages and Extremes. http://cirrus.dnr.state.sc.us/cgi-bin/sercc/cliMAIN.pl?nc3017. Accessed 26 July 2007. 
Stahle, D. W., 1979. Tree-dating of historical buildings in Arkansas. Tree-Ring Bulletin 39:1-28.

Stahle, D. W., M. K. Cleaveland, and J. G. Hehr, 1988. North Carolina climate changes reconstructed from tree rings: A.D. 372 to 1985. Science 240:1517-1519.

Stokes, M. A., and T. L. Smiley, 1996. An Introduction to TreeRing Dating. University of Arizona Press, Tucson.

Swetnam, T. W., M. A. Thompson, and E. K. Sutherland, 1985. Using dendrochronology to measure radial growth of defoliated trees. USDA Forest Service, Agricultural Handbook 639.
Van Lear, D. H., W. D. Carroll, P. R. Kapeluck, and R. Johnson, 2005. History and restoration of the longleaf pinegrassland ecosystem: Implications for species at risk. Forest Ecology and Management 211(1-2):150-165.

Wright, H. A., and A. W. Bailey, 1982. Fire Ecology: United States and Southern Canada. John Wiley and Sons, New York.

Received 14 August 2007; accepted 3 September 2008. 